\title{
Dynamics in debris-flow activity on a forested cone - A case study using different dendroecological approaches
}

\author{
Michelle Bollschweiler*, Markus Stoffel, Dominique M. Schneuwly \\ Laboratory of Dendrogeomorphology, Groupe de Recherche en Géomorphologie (GReG), Department of Geosciences, Geography, \\ University of Fribourg, 1700 Fribourg, Switzerland
}

\begin{abstract}
Dendrogeomorphological analyses of trees affected by debris flows have regularly been used to date past events. However, this method has always been limited to forested cones where trees registered the impact of previous events. The minimum age dating of trees growing in the debris deposits can, in contrast, provide information on the latest possible moment of past activity. In this paper, we report on results obtained from a combination of these two approaches on a forested cone in the Valais Alps (Switzerland). A detailed geomorphic map in a scale of 1:1000 served as a basis for the sampling strategy. Disturbed Larix decidua Mill. and Picea abies (L.) Karst. trees growing in the deposits allowed reconstruction of 49 events between AD 1782 and 2005 as well as the determination of the spatial extent of events. In the debris-flow channels where survivor trees are missing, we selected the oldest post-event trees and assessed their age by counting their growth rings. Missing rings due to lack of center as well as to sampling height were added so as to determine real tree age. The combination of the dendrogeomorphological event reconstruction with the assessment of germination dates of successor trees allowed realistic approximation of the minimum time elapsed since the last debris-flow activity in 23 of the 29 channels present on the current-day cone surface. In general, channels in the northern part of the cone and those close to the currently active channel generally show signs of (sub-) recent activity with one last overbank sedimentation event in the 1980s, whereas signs of debris-flow activity are absent from the channels in the outermost part since the late 19th century. As a consequence of the deeply incised channel and the stabilization measures undertaken along the banks, signs of debris flows are missing in the tree-ring record for the past two decades.
\end{abstract}

Keywords: Debris flow; Tree-ring analysis; Dendrogeomorphology; Dendrochronology; Landform surface dating; Swiss Alps

\section{Introduction}

Geomorphic processes are widespread phenomena in mountain regions, where their repeated occurrence may result in characteristic landforms such as debris-flow cones. In inhabited areas, these mass movements may cause damage to transportation corridors and buildings or even lead to the loss of lives. As a consequence, the understanding of the debris-flow process as well as the behavior of events in space and time is crucial for the mitigation of hazards and risks (Carrara et al., 1999; Cardinali et al., 2002; Pasuto and Soldati, 2004). For many torrents in Alpine regions, however, systematic acquisition of data on past debris flows only started after a series of

\footnotetext{
* Corresponding author. Tel.: +41 2630092 49; fax: +41 263009746.

E-mail address: michelle.bollschweiler@unifr.ch (M. Bollschweiler).
}

catastrophic events in 1987 and 1993 (Haeberli et al., 1990; Rickenmann and Zimmermann, 1993; Zimmermann et al., 1997); there is still a considerable lack of knowledge on earlier events for many regions. Thus the reconstruction of past activity is essential for the understanding of current debris-flow dynamics in mountain torrents and possible future developments due to potential climatic change (Goudie, 2006).

The most accurate method for dating events over several centuries in the past is dendrogeomorphology. This technique is based on the fact that trees growing in temperate climates form annual growth rings and that they record external disturbances such as climatic fluctuations or geomorphic events in their treering series (Schweingruber, 1996, 2001). Given that a tree is directly impacted by a geomorphic event, tree-ring dating can pinpoint the year or even the season in which the disturbance occurred. Research on the reactions of trees to geomorphic events 


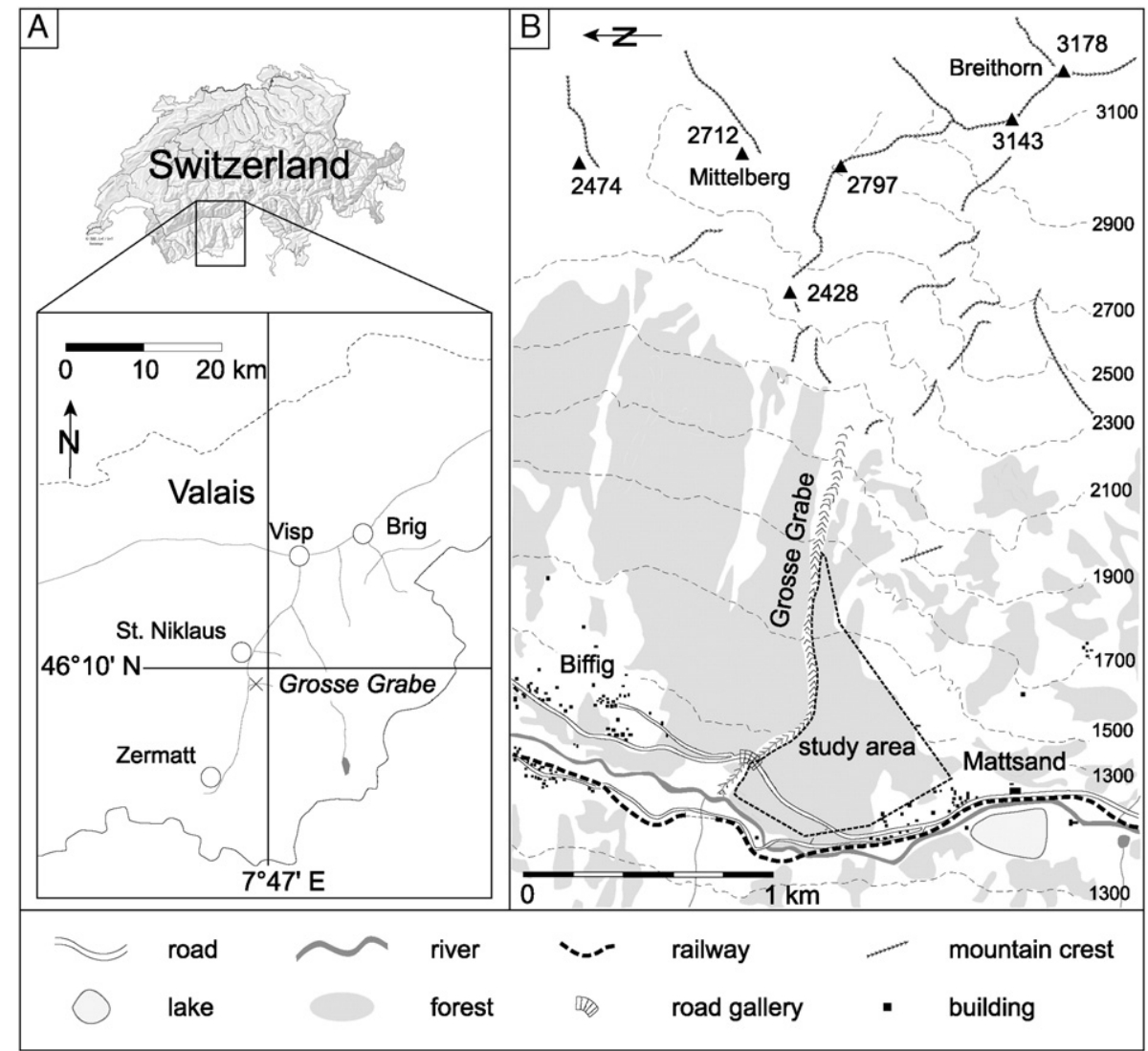

Fig. 1. A. The study site is located in the Matter Valley close to St. Niklaus. B. Sketch map of the study site with the Grosse Grabe torrent and the large debris-flow cone (= study area)

has commonly been based on Alestalo's (1971) pioneering results, as he was the first to provide detailed results on the influence of slope movements on tree-ring formation. More recently, dendrogeomorphological techniques have been widely used to reconstruct the frequency, magnitude or spatial patterns of rockfall activity (Stoffel et al., 2005a; Perret et al., 2006) or for the calibration of rockfall models (Stoffel et al., 2006). In a similar way, past snow avalanches (Butler et al., 1992; Rayback, 1998; Hebertson and Jenkins, 2003) or landslides (Fantucci and SorrisoValvo, 1999; Stefanini, 2004) have been assessed with tree rings.

Previous debris-flow studies using dendrogeomorphological methods primarily focused on the dating of individual events or deposits (Stefanini and Ribolini, 2003; May and Gresswell, 2004), on the reconstruction of magnitudes and/or frequencies (Strunk, 1997; Wilkerson and Schmid, 2003; Bollschweiler and Stoffel, 2007) or on a comparison of reconstructed debris-flow data with flooding events in neighboring rivers (Stoffel et al., 2005b). Further, the spatial patterns of past debris flows on forested cones have been studied by Bollschweiler et al. (in press). Based on treering evidence, Stoffel and Beniston (2006) were able to identify changes in the seasonality of debris-flow activity since the Little Ice Age.

Particularly large or devastating debris flows may eliminate entire forest stands, rendering the reconstruction of previous events impossible with dendrogeomorphological methods. Since cleared surfaces are normally recolonized by seedlings in the years following the devastating event, germination ages of trees growing on landform surfaces have also been used in a number of studies to estimate the time of creation of new landforms or the time of surface-clearing disturbances to existing landforms (Sigafoos and Hendricks, 1969; Shroder, 1980; McCarthy and Luckmann, 1993; Winter et al., 2002). Similarly, this method can be used to date surfaces cleared by debris-flow activity.

The aim of this study was to combine dendrogeomorphological analyses with an assessment of germination dates of successor trees in order to understand the dynamics of past debris-flow events on a forested cone in the Valais Alps, Switzerland. In a first step, all forms related to debris-flow activity such as lobes, levees and abandoned debris-flow channels were mapped in a scale of 1:1000. Disturbed trees growing in these deposits were analyzed to reconstruct the debris-flow frequency and the spatial extent of previous events. For the sectors of the cone where no disturbed trees are present, undisturbed trees growing in previously active debris-flow channels were sampled and their age assessed so as to approximate the minimum time elapsed since the last event in these channels. The coupling of data on events in channels with the minimum age dating allowed reconstruction of the spatial dynamics of debris-flow activity on the cone.

\section{Study site}

The study of past debris-flow dynamics was conducted on the cone of the Grosse Grabe torrent, located on the west-facing 

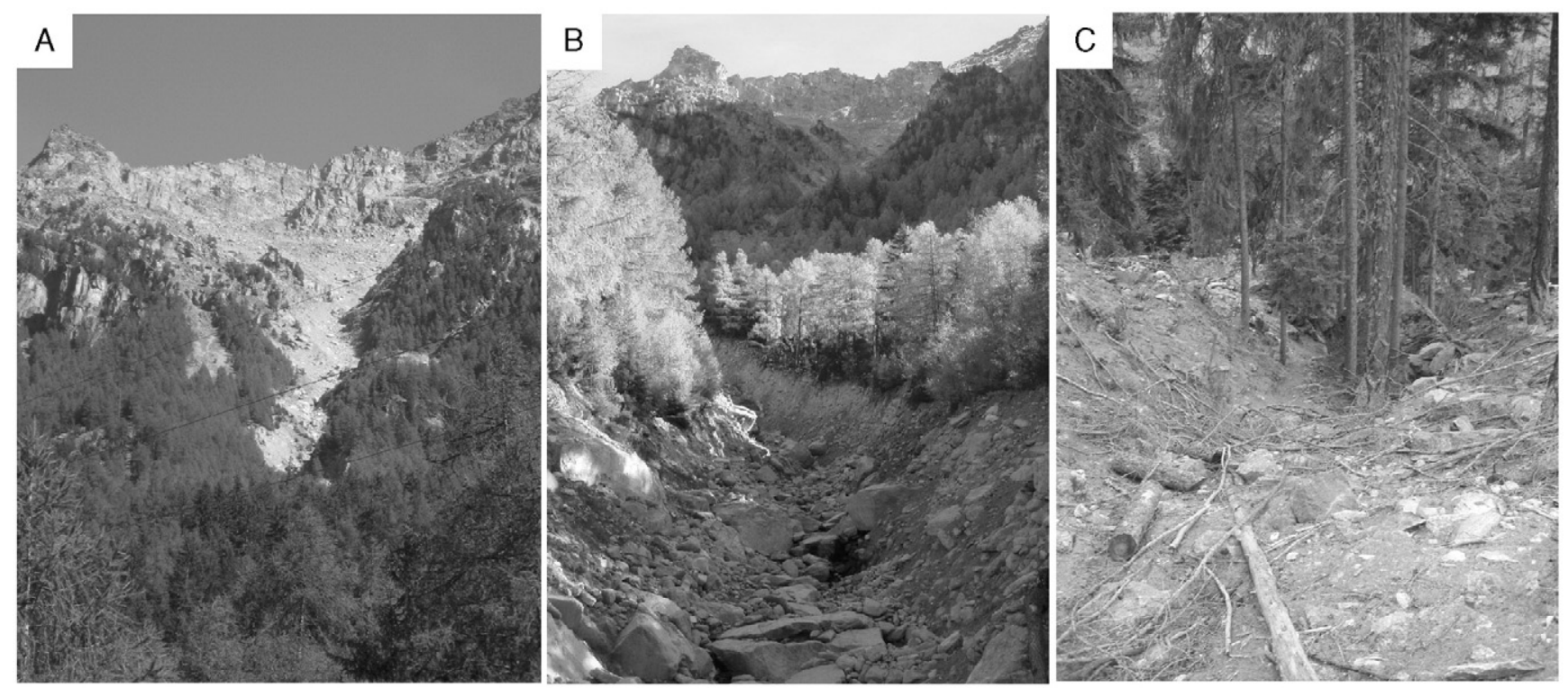

Fig. 2. A. View of the upper catchment area. B. The currently active debris-flow channel passes a forest of Larix decidua Mill. und Picea abies (L.) Karst. trees. C. On the debris-flow cone, a large number of previously active channels can be identified.

slope of the Matter Valley (Valais, Swiss Alps; $46^{\circ} 10^{\prime} \mathrm{N}$, $7^{\circ} 47^{\prime}$ E; Fig. 1). The catchment area (Fig. 2A) of the torrent totals $1.5 \mathrm{~km}^{2}$ and extends from the Breithorn summit (3178 m a.s.1.) to the Mattervispa River (1200 m a.s.1.). The considerable gradient between the source and the cone results in steep torrent topography (on average $25^{\circ}$; Fig. 2B). The upper part of the catchment is dominated by gneissic rocks belonging to the crystalline Mischabel unit, while in the lower part, debris originating from various gravitational processes (i.e. rockslides, rockfall) cover the bedrock (Labhart, 2004). A considerable part of the upper catchment is located above tree line and characterized by steep scree slopes without any vegetation or dominated by scarce patches of alpine grass. The debris-flow cone extends from $1200 \mathrm{~m}$ a.s.l. to $1600 \mathrm{~m}$ a.s.l. and is vegetated by a forest primarily composed of European larch (Larix decidua Mill.) and Norway spruce (Picea abies (L.) Karst.; Fig. 2C). On the cone, slope gradients average $14^{\circ}$ and deposits of past debris flows can exclusively be found south of the currently active channel. In the lowermost part of the cone, a gallery was built in 1970 to protect the main road connecting Zermatt to Visp from debris flows. Anthropogenic influence on the cone is most pronounced in its southernmost part, where deposits have been removed for the construction of houses of the hamlet of Mattsand. The area below the main road is not covered in this study, since deposits in this part of the cone have been considerably reshaped and logging activity has become important in the past few decades. Similarly, we did not analyze trees growing on the uppermost part of the cone, as trees may have been influenced by rockfall or snow avalanche activity as well. Archival data on past events only cover the last 13 years, with debris-flow activity noted for 1993, 1994, 1999 and 2000. Data also suggest that debris flows at Grosse Grabe were most frequently triggered during prolonged rainfall events (Seiler and Zimmermann, 1999).

\section{Methods}

\subsection{Geomorphic mapping}

In a first analytical step, all forms and deposits related to previous debris-flow activity (i.e. lobes, levees or abandoned channels) were mapped in a scale of 1:1000. Due to the presence of the forest on the cone as well as the shielding effect of the high summits except from the north, GPS devices could not be used. Therefore, the map was based on detailed measurements using compass, tape measure and inclinometer.

\subsection{Sampling strategy}

L. decidua and P. abies trees that had obviously been disturbed by previous debris-flow events were cored using a Suunto increment borer (max. length $40 \mathrm{~cm}, \varnothing 6 \mathrm{~mm}$ ). Within this study, we preferably selected trees that showed scars, candelabra growth, exposed root systems as well as buried or tilted stem bases resulting from the impact of past events. Two cores per tree were normally extracted, one in the flow direction, the other on the opposite side of the trunk. Sampling height was chosen according to the morphology of the stem. Tilted or injured trees were sampled at the height of the disturbance, whereas decapitated trees or trees with a buried stem base were cored as close to the ground as possible so as to gather as much information as possible. In total, 71 strongly affected $L$. decidua and P. abies trees were sampled with 150 cores for this study.

In the channels located in the southern sectors of the cone, disturbed trees were very scarce and sometimes even totally absent. Therefore, we sampled 72 undisturbed trees for minimum age dating in these sectors. One core per tree was extracted as close to the ground as possible to minimize the loss of increment rings due to the sampling height. The position of 
all trees cored - disturbed and minimum age dating - was accurately marked on the geomorphic map.

In addition to the disturbed trees and the trees sampled for minimum age dating, we cored $17 \mathrm{~L}$. decidua (34 increment cores) and 18 P. abies (36 increment cores) trees outside the debris-flow cone that had not been affected by past geomorphic activity. These samples were then used to build a reference chronology representing normal growth conditions at the study site, i.e. those influenced by climate or insect outbreaks (Douglass, 1929; Cook and Kairiukstis, 1990; Vaganov et al., 2006).

\subsection{Dating of debris-flow events and reconstruction of their spatial extent}

The samples from the disturbed trees were analyzed using standard dendrochronological methods (see Bräker, 2002). Individual steps included surface preparation, counting of tree rings, measuring of tree-ring widths using a LINTAB measuring table and TSAP 3.0 software (Time Series Analysis and Presentation; Rinntech, 2006). Growth curves of trees were then crossdated with the reference chronology. Afterwards, tree-ring series were analyzed visually so as to identify growth disturbances caused by past debris-flow events. The presence of tangential rows of traumatic resin ducts as well as callus tissue bordering injuries (Stoffel et al., 2005c; Perret et al., 2006) were noted on skeleton plots (Schweingruber et al., 1990). The study of the ring-width series as well as the visual inspection of samples further allowed determination of abrupt growth decrease after stem burial or root exposure (Schweingruber, 1996, 2001), the onset of compression wood after stem tilting (Giardino et al., 1984; Braam et al., 1987; Fantucci and Sorriso-Valvo, 1999) or abrupt growth increase in survivor trees after the elimination of neighbors (Schweingruber, 1996). The identification of events was based on the number of samples simultaneously showing a growth disturbance as well as on the distribution of affected trees on the cone. Thereafter, we grouped GD occurring simultaneously in different trees and defined criteria for the determination of event years: For reasons of limited sample depth (i.e. limited age of trees), strong and abrupt GD were considered an event

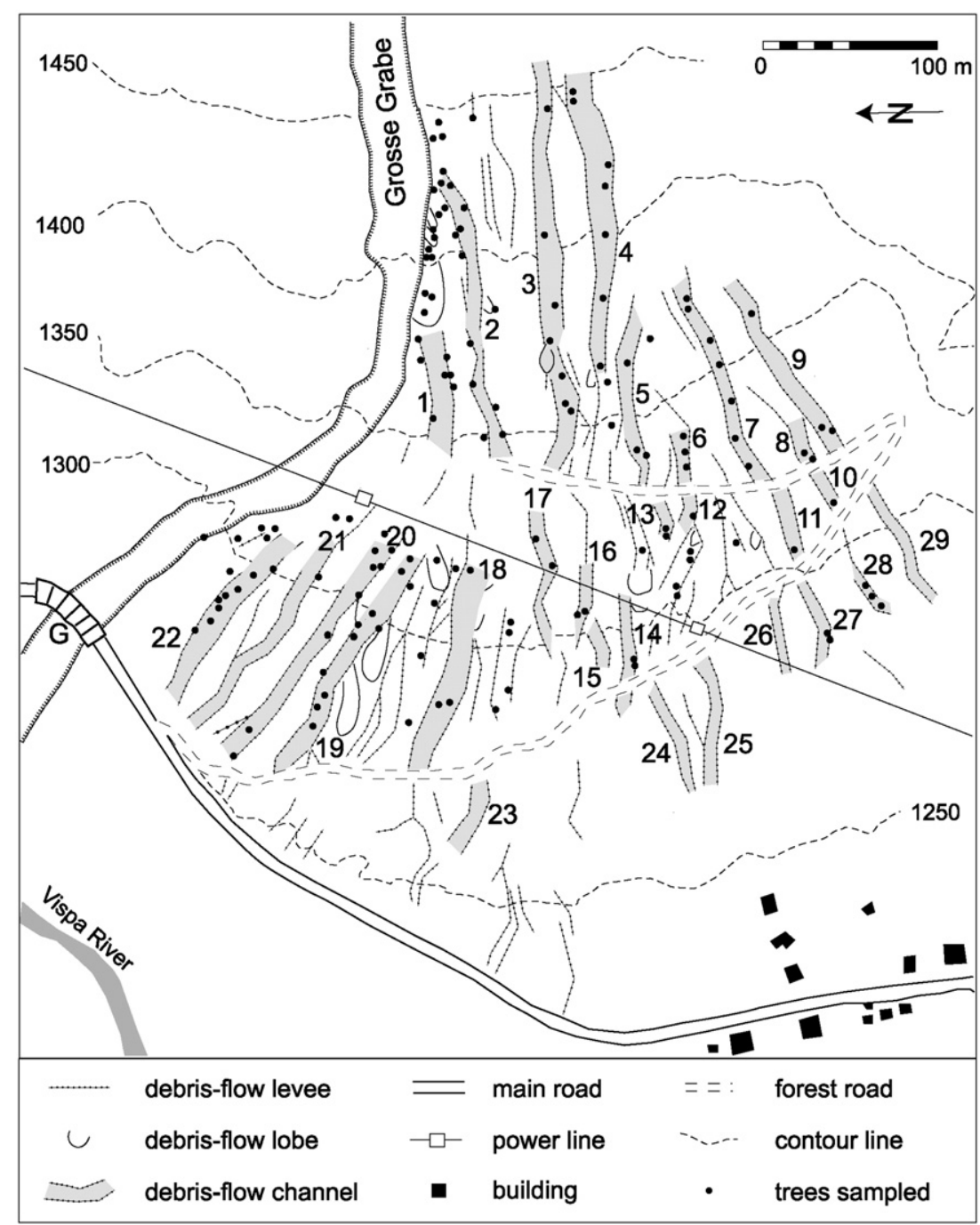

Fig. 3. Detailed geomorphic map (original scale: 1:1000) of all debris-flow forms and deposits identified on the cone. The main road is protected by a road gallery (G). In total, 29 channels, 61 additional segments of levees as well as 14 lobate deposits could be identified. 


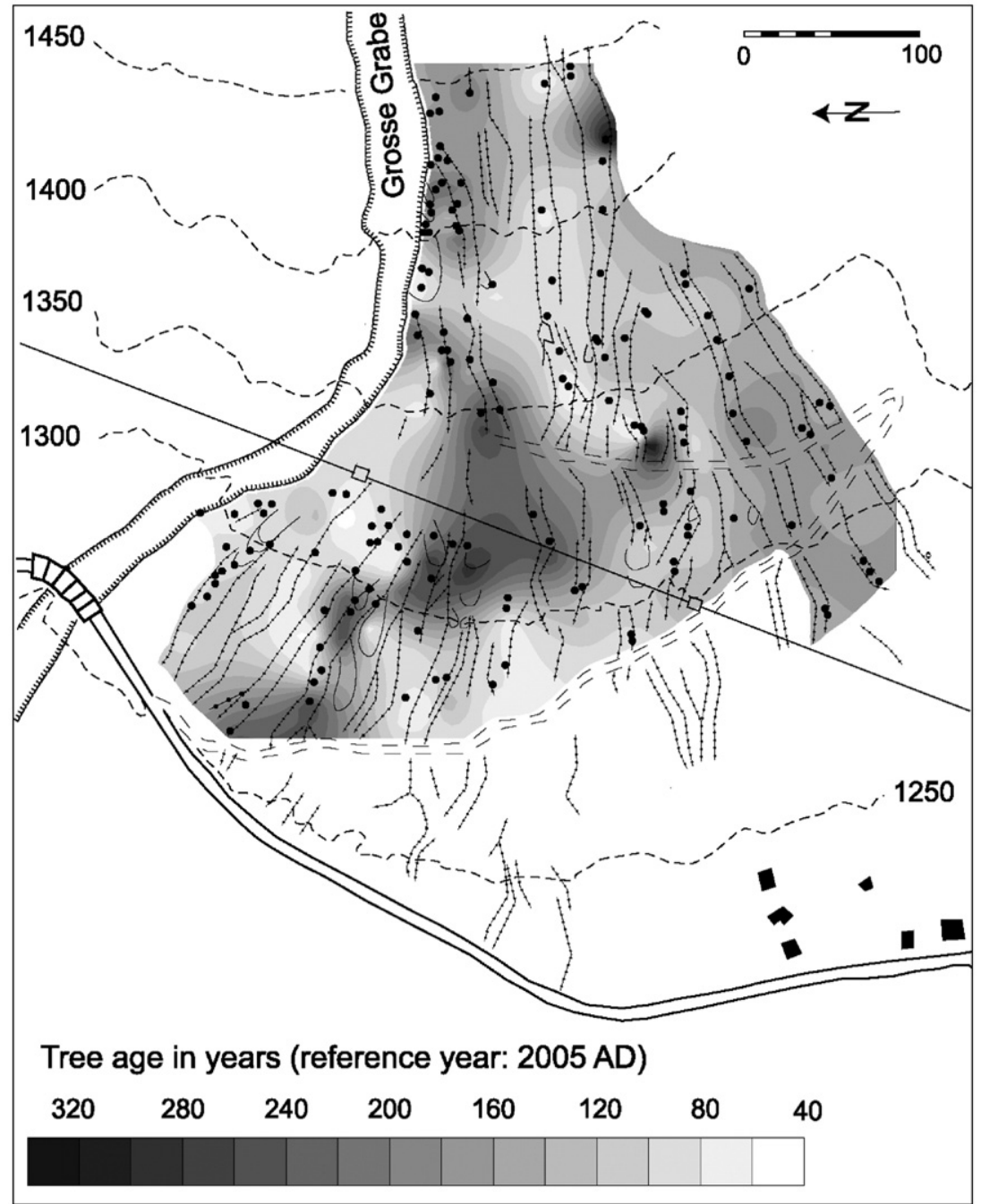

Fig. 4. Age structure of the forest stand on the cone. The oldest trees are located on the central as well as in the uppermost part of the cone. The oldest tree reached sampling height in $\mathrm{AD} 1649$, whereas the youngest tree is only 42 years old. Trees in the lowermost part of the cone close to the torrent are much younger than the average, which is 140 years.

year for the period $1780-1910$ as soon as signs were present in at least two trees. However, if only one individual tree showed GD in a year, the event was regarded as probable and illustrated with a dashed line in the debris-flow frequency. In contrast, (i) weak GD identified in several cores or (ii) abrupt GD identified in one individual tree were disregarded for events occurring after AD 1910, and only the years with at least two abrupt GD identified in the samples were kept for further analysis. In addition, we identified the position of all trees with growth reactions during the same event on the geomorphic map. This representation of trees affected during individual events allowed reconstruction of the spatial extent of events on the cone as well as an assessment of the activity in currently abandoned channels.

\subsection{Minimum age dating}

Tree germination rates are best determined by counting the annual growth rings in a cross section taken from the root crown (i.e. germination) level (McCarthy et al., 1991). However, destructive sampling is not always possible in protection forests.
On the other hand, branches, obstacles and rot may require sampling positions higher up on the stem. In these cases, an age correction factor needs to be added to compensate for the time a tree takes to grow to sampling height (McCarthy et al., 1991). A basic assumption of several height-age models is that apical growth is equally proportioned within a sampled section (e.g. Carmean, 1972; Lenhart, 1972; Schweingruber, 1996). Accordingly, averaged data should provide an accurate estimate of apical growth (McCarthy et al., 1991). Therefore, we divided tree height by the number of tree rings to get an average rate for

Table 1

Growth disturbances (GD) assessed in the 150 samples of strongly affected Larix decidua Mill. and Picea abies (L.) Karst. trees

\begin{tabular}{lcr}
\hline & Amount & $\%$ \\
\hline Tangential rows of traumatic resin ducts & 121 & 50 \\
Compression wood & 45 & 19 \\
Growth increase & 42 & 17 \\
Growth decrease & 26 & 11 \\
Injuries & 8 & 3 \\
\hline Total & 242 & 100
\end{tabular}




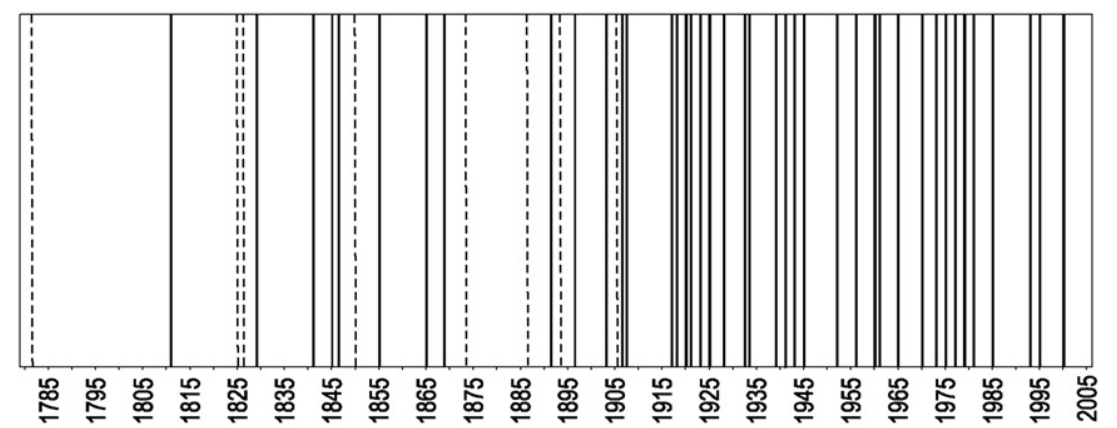

Fig. 5. Minimum debris-flow frequency for the Grosse Grabe torrent. In total, 49 events between AD 1782 and 2005 were reconstructed. Only a limited number of events could be reconstructed for the 19th century. Dashed lines indicate those events that were dated via the presence of GD occurring in one tree only.

the yearly apical increment for each tree. The sampling height was then divided by the yearly increment so as to obtain the number of missing rings. In addition, the number of missing rings was estimated whenever the pith was not present on the core. This correction was undertaken using a transparent sheet with concentric rings (Bosch and Gutiérrez, 1999). In contrast, we did not perform an age correction for the colonization time gap (Pierson, 2007) in this study, i.e. an estimate of time elapsed between the last debris-flow event in a channel and the germination of pioneer trees. As the tallest trees growing in a channel are not necessarily the oldest ones, we sampled - as far as possible - several trees per channel so as to minimize the risk of disregarding the oldest post-event tree.

\subsection{Determination of last moment of activity}

For the determination of the last moment of debris-flow activity in the currently abandoned channels, we dated the last event by means of dendrogeomorphological methods and the sampling of disturbed trees. In a second step, the germination date of the oldest tree was determined for channels where none of the trees of the present-day forest stand showed disturbances caused by past debris-flow activity. The coupling of data on debris-flow events with data on minimum ages of undisturbed trees growing in previously active channels allowed determination of the minimum time elapsed since the last event. This procedure allowed assessment spatio-temporal dynamics of past debris flows on the entire cone.

\section{Results}

\subsection{Geomorphic mapping}

On the debris-flow cone of the Grosse Grabe torrent, an area of 30 ha was mapped in a scale of 1:1000 and 29 abandoned channels were identified on its present-day surface. In addition, 61 segments of levees were mapped. These levees were comparably short and/or isolated and could therefore not be associated with a channel. Lobate deposits are relatively scarce with only 14 forms identified on the cone. Fig. 3 shows all forms mapped on the cone as well as the position of all trees sampled within this study. It can also be seen from Fig. 3 that the channels and their lateral levees are best developed in the upper part of the cone. In contrast, channels are less deeply incised and the debris-flow forms much smoother in the lower segments of the cone between the power line and the main road. It is also in this sector that most of the lobate deposits can be found. Below the main road, no deposits were mapped because of the strong anthropogenic influence.

\subsection{Age structure of the stand}

The average age of all trees sampled on the cone is 140 years (STDEV: 66 years). The oldest tree cored shows 356 tree rings at sampling height (AD 1649), while the youngest tree reached breast height only in AD 1963. As can be seen from Fig. 4, the age structure of the trees selected for analysis is quite heterogeneous. The oldest trees can be identified in the central part of the cone but a single old tree is located on the uppermost part of the cone. In addition, trees growing on the uppermost part close to the currently active debris-flow channel show comparably high ages with an average of 165 years. In contrast, young trees are located on the lower part of the cone close to the active channel and in channel 22, where most trees reached sampling height in the early 20 th century.

\subsection{Growth disturbances and debris-flow frequency}

The 71 L. decidua and P. abies trees sampled on the cone allowed identification of 242 growth disturbances (GD;

Table 2

Number of trees showing GD after the incidence of a debris flow in particular years

\begin{tabular}{|c|c|c|c|c|c|c|c|c|c|c|c|c|c|c|c|c|c|}
\hline Year A.D. & 2000 & 1995 & 1993 & 1985 & 1981 & 1979 & 1977 & 1975 & 1973 & 1970 & 1965 & 1961 & 1960 & 1956 & 1952 & 1945 & 1943 \\
\hline No. of trees with GD & 2 & 4 & 2 & 5 & 6 & 5 & 10 & 9 & 6 & 5 & 4 & 3 & 2 & 5 & 5 & 10 & 8 \\
\hline Year A.D. & 1941 & 1939 & 1934 & 1933 & 1928 & 1925 & 1923 & 1921 & 1920 & 1918 & 1917 & 1908 & 1907 & 1906 & 1903 & 1897 & \\
\hline No. of trees with GD & 6 & 5 & 8 & 4 & 9 & 5 & 8 & 7 & 6 & 10 & 10 & 4 & 3 & 1 & 2 & 2 & \\
\hline Year A.D. & 1894 & 1892 & 1887 & 1874 & 1869 & 1865 & 1855 & 1850 & 1847 & 1845 & 1841 & 1829 & 1826 & 1825 & 1811 & 1782 & \\
\hline No. of trees with GD & 1 & 3 & 1 & 1 & 2 & 3 & 2 & 1 & 3 & 2 & 2 & 1 & 1 & 2 & 2 & 1 & \\
\hline
\end{tabular}



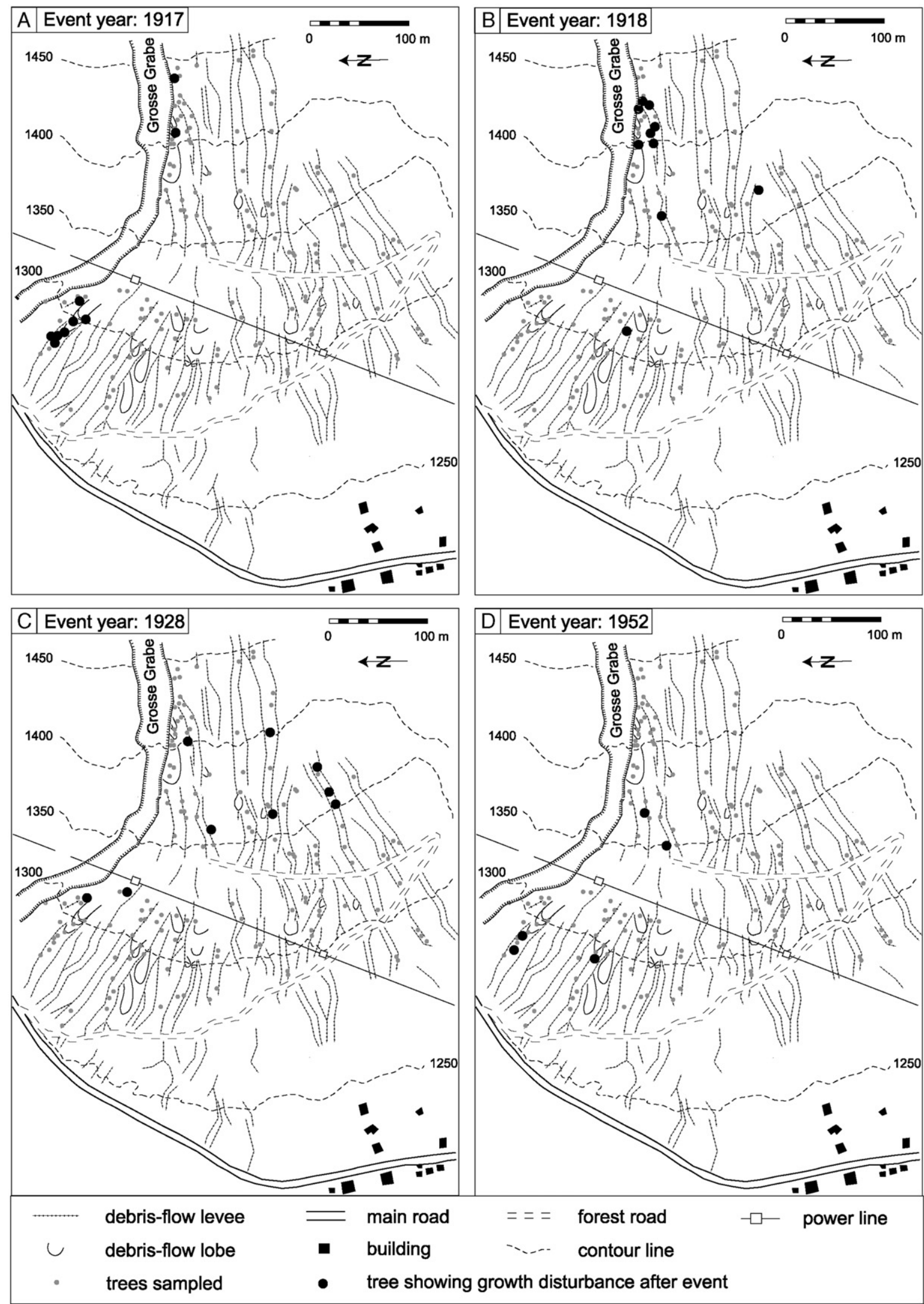

Fig. 6. Spatial distribution of trees showing growth disturbances following the events of 1917 (A), 1918 (B), 1928 (C) and 1952 (D) 
Table 1). Injuries or the adjacent callus tissue were only occasionally identified on the increment cores $(3 \%)$, whereas tangential rows of traumatic resin ducts (TRD) were commonly found in the samples (50\%). Abrupt growth changes such as sudden increase or decrease in the yearly ring widths were found in $17 \%$ and $11 \%$ of the samples, respectively. The onset of reaction wood after tilting was found in $19 \%$.

In total, the analysis of GD occurring simultaneously in different trees allowed the reconstruction of 49 event years between AD 1782 and 2005. Fig. 5 gives the reconstructed debrisflow frequency for the Grosse Grabe torrent. As can be seen from the illustration, the reconstruction yielded data for only a limited number of events in the 19th century. In contrast, the tree-ring records suggest several periods with increased activity during the 20th century. Such clustering of events can primarily be identified for the periods 1905-1907 or 1917-1928 as well as between 1970 and 1982. In addition, Table 2 gives details on the number of trees showing GD as a result to an event year.

\subsection{Spatial extent of past events}

The spatial extent of past events was assessed by investigating the position of all trees showing GD in a specific year. In general,

Table 3

A combination of data on the moment of the last event with the age of the oldest post-event trees growing in channels was used to determine the minimum time elapsed since the last event in previously active debris-flow channels

\begin{tabular}{lllrlll}
\hline $\begin{array}{l}\text { Channel } \\
\text { no. }\end{array}$ & $\begin{array}{l}\text { No. of } \\
\text { disturbed } \\
\text { trees }\end{array}$ & $\begin{array}{l}\text { No. of } \\
\text { undisturbed } \\
\text { trees }\end{array}$ & $\begin{array}{l}\text { No. of } \\
\text { events }\end{array}$ & $\begin{array}{l}\text { Last } \\
\text { event }\end{array}$ & $\begin{array}{l}\text { Age of } \\
\text { oldest treee }\end{array}$ & $\begin{array}{l}\text { No } \\
\text { event } \\
\text { since }\end{array}$ \\
\hline 1 & 7 & 0 & 8 & 1979 & 1786 & 1979 \\
2 & 15 & 0 & 28 & 1985 & 1735 & 1985 \\
3 & 0 & 7 & 0 & - & 1912 & 1912 \\
4 & 1 & 7 & 7 & 1956 & 1670 & 1956 \\
5 & 1 & 2 & 2 & 1908 & 1649 & 1908 \\
6 & 0 & 3 & 0 & - & 1898 & 1898 \\
7 & 0 & 7 & 4 & 1939 & 1834 & 1939 \\
8 & 0 & 2 & 0 & - & 1819 & 1819 \\
9 & 0 & 3 & 2 & 1855 & 1841 & 1871 \\
10 & 0 & 1 & 0 & - & 1866 & 1866 \\
11 & 0 & 1 & 0 & - & 1834 & 1883 \\
12 & 0 & 1 & 0 & - & 1894 & 1894 \\
13 & 0 & 2 & 0 & - & 1879 & 1879 \\
14 & 0 & 2 & 0 & - & 1909 & 1909 \\
15 & 0 & 0 & 0 & - & - & - \\
16 & 1 & 1 & 3 & 1975 & 1873 & 1925 \\
17 & 1 & 1 & 1 & 1925 & 1752 & 1925 \\
18 & 1 & 2 & 3 & 1973 & 1867 & 1973 \\
19 & 8 & 3 & 9 & 1975 & 1740 & 1975 \\
20 & 3 & 6 & 5 & 1945 & 1763 & 1945 \\
21 & 3 & 0 & 4 & 1965 & 1875 & 1970 \\
22 & 8 & 2 & 16 & 1977 & 1870 & 1977 \\
23 & 0 & 0 & 0 & - & - & - \\
24 & 0 & 0 & 0 & - & - & - \\
25 & 0 & 0 & 0 & - & - & - \\
26 & 0 & 0 & 0 & - & - & - \\
27 & 0 & 2 & 0 & - & 1855 & 1855 \\
28 & 0 & 3 & 0 & - & 1817 & 1817 \\
29 & 0 & 0 & 0 & - & - & - \\
\hline & 0 & 1 & & & & \\
\hline
\end{tabular}

For the location of the individual channels see Fig. 3. events could only be reconstructed for the northern part of the cone. In the southern part, there were no disturbed trees, which did not allow the reconstruction of previous events by means of dendrogeomorphological methods. Fig. 6 illustrates the spatial patterns of four different debris-flow events and the position of all trees with GD during the years in question: In 1917 (Fig. 6A), debris-flow surges apparently passed south of the current channel at $\sim 1320 \mathrm{~m}$ a.s.l. and caused damage to trees in channel 22 (for channel numbers see Fig. 3). In contrast, a debris-flow event in 1918 (Fig. 6B) caused damage primarily to seven trees sampled on the uppermost part of the cone. Debris-flow material seems to have left the current channel at $\sim 1430 \mathrm{~m}$ a.s.l., passing through channel 2 on its way further down the cone. In addition, the event even disturbed trees in channel 19 on the lower part of the cone. A series of debris-flow surges dated to 1928 (Fig. 6C) must have left the current channel at the cone apex, thus activating channels 2, 4 and 7 located in the southern part of the study area. In addition, some of the material caused GD to trees growing in channels 21 and 22. Fig. 6D provides the spatial distribution of a limited number of trees that were damaged by debris-flow activity in 1952. Here, debris-flow surges apparently passed through channels 1 and 2 and even reached the lower parts of the cone.

From our data, it also appears that - throughout the period of reconstruction - debris-flow activity was greatest in channels 2 and 22 . In channel 2 , there is evidence for 28 previous events and at least 16 events caused damage to trees growing in or next to channel 22 (see Table 2). In contrast, signs of past activity are normally lower for the other channels, with only one to nine events identified. Overall, debris-flow events could be reconstructed in 13 of the 29 channels. In contrast, trees did not show any signs of past activity in the 16 other channels identified on the cone.

\subsection{Approximation of last moment of past activity}

Since past debris-flow events and their spatial extent could only be reconstructed on the northern part of the cone, we determined the age of the oldest post-event trees to approximate the minimum time elapsed since the last moment of debris-flow activity on the southern part of the cone. For the unaffected trees considered for the minimum age dating, two steps of age correction were carried out so as to determine the real age as precisely as possible. First, missing rings due to the sampling height had to be added. The yearly vertical increment ranged from 0.1 to $0.5 \mathrm{~m}$ with an average of $0.21 \mathrm{~m}$ (STDEV: $0.09 \mathrm{~m}$ ). Therefore, the missing rings due to sampling height averaged 3.3 years (min. 1; max. 9; STDEV: 2.0 years). Similarly, additional year rings added to correct errors due to the absence of the pith on the sample varied between 1 and 20 years with an average of 5.9 years per core (STDEV: 5.2 years).

In a subsequent step and in order to obtain a more complete image of debris-flow dynamics at the study site, reconstructed data on past debris-flow events were coupled with data on the age of the oldest trees growing in the abandoned debris-flow channels. Table 3 gives an overview of the channels, the number of trees sampled per channel, the number of events reconstructed as well as the age of the oldest tree. A combination of all these data was then used to assess the minimum time that had elapsed since the last event. 

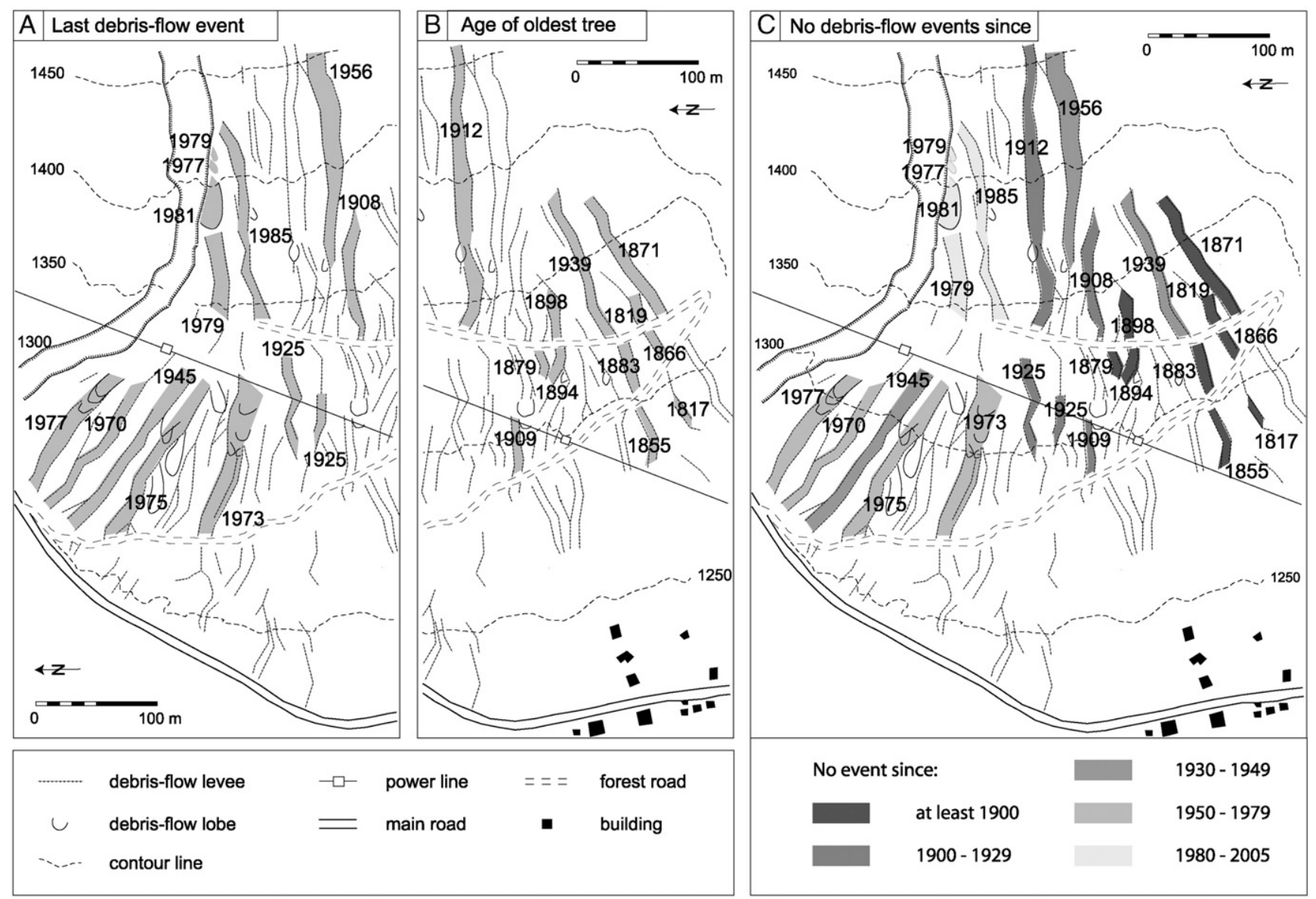

Fig. 7. A. The last debris-flow event in channels with disturbed trees took place between 1908 and 1985. B. The oldest undisturbed trees in channels reached sampling height between 1817 and 1939. C. A combination of data on past events including minimum ages of undisturbed trees growing in channels provides information on the latest possible moment for debris-flow activity in particular channels.

Fig. 7A illustrates the channels where past debris-flow activity could be dated by means of dendrogeomorphological methods. Here, years shown indicate the last moment of last activity in these channels. By way of example, it can be seen that trees in channels 16 and 17 recorded a last event in 1925. In contrast, no event could be identified in channel 5 after 1908. The last events in the channels located next to the currently active one were registered in AD 1979 and 1985, respectively.

Fig. 7B provides the age of the oldest living trees growing in channels where signs of past debris-flow activity are absent. The calendar years are meant to provide an idea of the minimum time elapsed since the last event. Germination dates of the oldest living trees vary between AD 1817 and 1939.

The results of the two preceding approaches are coupled in Fig. 7C, with calendar years indicating the latest possible moment of debris-flow activity in the channel. From our data, we can see that the time elapsed since the last debris-flow activity clearly increases with the distance from the currently used channel, with the last activity identified in the early 1980s close to the current channel, whereas GD in trees are missing in the southern and central sectors of the cone since the late 19th century.

\section{Discussion}

In this study, we report on a reconstruction of debris-flow events on a forested cone in the Valais Alps (Switzerland) based on detailed geomorphic mapping and tree-ring analyses. Dendrogeomorphological investigations of 71 heavily affected L. decidua Mill. and P. abies (L.) Karst. trees allowed reconstruction of the frequency and the spatial extent of past debris-flow activity. In total, 49 events could be identified for the period AD 1782-2005. In addition, we determined the germination ages of the oldest trees in those channels where trees were missing obvious signs of past debris-flow activity. These dates served as an approximation of the minimum time elapsed since the last possible event in channels.

The debris-flow frequency represents the minimum number of events that occurred in this torrent in the recent past. The study of past events was mainly limited by the age of the trees, which averaged only 140 years. Even though the oldest tree reached sampling height in AD 1649, only a limited number of trees used in this study were older than 200 years. Therefore, the age of the trees appears to be much lower than those at other sites in the valley and is basically due to considerable logging activity on the cone. As a result, the increasing number of events 
in the 20th century is at least partially due to an increase in the number of sampled trees.

In addition, it is feasible that changing climatic conditions and the abundance of summer precipitation events at the end of the Little Ice Age and in the early 20th century (Pfister, 1999; Stoffel and Beniston, 2006) may have had an effect on the release of debris flows and therefore on the frequency as well. At the same time, the apparent decrease in event frequency that starts to emerge from the tree-ring reconstruction in the 1980 s was primarily due to considerable channel incision (about $6-$ $8 \mathrm{~m}$ ) and to bank stabilization measures, which prevented present-day debris-flow surges from leaving the channel. As a result, and on the basis of observations recorded on century-old topographic sheets of the study region, we should not overlook the fact that channel incision events may have occurred in the past as well, and that our tree-ring based reconstruction may have failed to detect small debris-flow surges that did not leave the channel and cause growth disturbances (GD) to trees growing on the cone.

The age structure of the stand was determined by counting the number of tree rings present on the increment cores. An interpolation allowed representation of the spatial distribution of tree ages on the cone. The map clearly indicates that a large number of trees growing close to the present-day channel in the lower part of the cone reached sampling height in the early 20th century. As human interventions cannot be considered the main reason for this concentration of germination and as other geomorphic processes are absent here, it is feasible that a very large debris-flow event at the end of the 19th or in the earliest days of the 20th century could have eliminated a previously existing stand and have left open space for the germination of new trees.

Tree-ring analyses in combination with detailed geomorphic mapping further allowed determination of the spatial extent of events. Nonetheless, the amount of data on the distribution of past events on the cone is mainly limited by the number and the age of trees showing signs of past events. Hardly any information on past events exists for the southernmost part of the cone, as geomorphic forms might be older than the ages attained locally by L. decidua Mill. and P. abies (L.) Karst. trees. Another reason for the absence of trees might be their elimination either by exceptionally large and devastating debris flows in the past or through logging activity on the cone. Nonetheless, we are confident that the spatial extent of past events could be realistically determined for at least the sectors close to the torrent.

Due to the absence of disturbed trees in the channels of the southern part of the cone, we selected 71 undisturbed trees for a minimum age dating of inactivity in these forms. The age of trees was determined through the counting of tree rings present on the increment cores. Thereafter, the number of rings missing to the pith was approximated with a transparent sheet with concentric rings. This approach - initially developed by Bosch and Gutiérrez (1999) - furnishes a realistic idea of the number of missing rings in cases where there are not too many rings missing before the pith. However, given that the center is distant from the location where the sample was taken and given that tree rings are narrow, the accuracy of the method remains limited. Furthermore, the approach used in this study is based on the assumption that growth of the innermost tree rings is constant and sudden changes in tree-ring width do not occur. As a result, it was not possible to account for such growth changes in this study. We are aware of these methodological limitations, and have to admit that there is probably no other way of assessing the real germination dates of disturbed trees. Nevertheless, we are convinced that the results presented on the minimum age of the tree are reasonably accurate. Similarly, we have to stress that the presence of growth reductions will more probably result in an underestimation rather than an overestimated of missing rings, which supports the idea of providing "minimum ages" of forms and deposits.

The same restrictions apply for the age correction due to the sampling height. Again, we assumed that the growth of the young seedling is constant. Sudden growth changes occurring in the rings that are only present below sampling height could not be identified and the age of the undisturbed trees might again have been underestimated. As a consequence, the approaches chosen for the minimum age dating of inactivity in debris-flow channels represent a valuable approximation for the estimation of the time elapsed since the last activity, but they tend - at the same time - to underestimate the real age of trees and, hence, the age of geomorphic forms in the present case.

Another factor that may influence the results is the time that passes between the moment of channel clearing by debris flows and the moment when seedlings start to recolonize the area. Pierson (2007) refers to this interval as germination lag time (GLT), while previous studies preferred the term "ecesis interval" (e.g. Desloges and Ryder, 1990; McCarthy and Luckmann, 1993). According to Pierson (2007), this GLT for surfaces newly formed through lahars varies between 1 and 14 years. In glacial forefields, the GLT is generally higher with 5 to 60 years (McCarthy and Luckmann, 1993). At our site, we believe that GLT are relatively short since climatic conditions are favorable for tree growth and seed sources are abundant. This assumption is further supported by personal observations made on a cone formed by a rockslide at Grossgufer (see Schindler et al., 1993) in the same valley in 1991. Here, colonization of the cone had already started in the year following the event. As a result, we deliberately did not account for GLT in our study, as it can be considered very low at the study site.

Even though the methods used have their limitations, this study allowed for the first time reconstruction of the spatial and temporal dynamics of debris-flow activity on a forested cone, where deposits are in some places older than the oldest trees.

\section{Conclusion}

The combination of different dendroecological methods allowed reconstruction of 49 event years between AD 1782 and 2005 as well as the determination of the minimum time elapsed since the last debris-flow event for previously active channels. For cones or sectors where trees are obviously influenced by debris flows, dendrogeomorphological methods analyzing distinct growth disturbances in the tree-ring series are suitable for the determination of event years. In combination with geomorphic mapping, the spatial extent of previous events can be determined. 
In contrast, for cones or sectors of cones where deposits of the current-day surface are older than trees growing in the deposits, this method is not applicable. However, tree ages of the oldest post-event trees growing in the previously active channels allow determination of the latest possible moment of debris-flow activity in these channels. Therefore, the approach presented here is appropriate especially for debris-flow cones with comparably young trees, either because of repeated and devastating debrisflow events that cleared entire surfaces or because of logging activity. The combination of both techniques - dating of growth disturbances and assessing tree age of post-event trees - allows determination of the spatio-temporal dynamics of past debrisflow activity over the past few centuries on forested cones.

\section{Acknowledgments}

The municipality of St. Niklaus and the Canton of Valais are warmly acknowledged for the financial support for this study. We would like to thank Simone Imseng and Sarah Gottet for the geomorphic mapping of the debris-flow cone. Prof. Michel Monbaron is kindly acknowledged for his financial and moral support. We would like to thank Heather Murray, who improved the English of this article.

\section{References}

Alestalo, J., 1971. Dendrochronological interpretation of geomorphic processes. Fennia 105, 1-140.

Bollschweiler, M., Stoffel, M., 2007. Debris flows on forested cones reconstruction and comparison of frequencies in two catchments in Val Ferret, Switzerland. Natural Hazards and Earth System Sciences 7, 207-218.

Bollschweiler, M., Stoffel, M., Ehmisch, M., Monbaron, M., in press. Reconstructing spatio-temporal patterns of debris-flow activity using dendrogeomorphological methods. Geomorphology.

Bosch, O., Gutiérrez, E., 1999. La sucésion en los bosques de pinus uncinata del pirineo. De los anillos de crecimiento a la historia del bosque. Ecologia 13, 133-171.

Braam, R.R., Weiss, E.E.J., Burrough, P.A., 1987. Spatial and temporal analysis of mass movement using dendrochronology. Catena 14, 573-584.

Bräker, O.U., 2002. Measuring and data processing in tree-ring research - a methodological introduction. Dendrochronologia 20, 203-216.

Butler, D.R., Malanson, G.P., Walsh, S.J., 1992. Snow-avalanche paths: conduits from the periglacial-alpine zone to the subalpine-depositional zone. In: Dixon, J.C., Abrahams, A.D. (Eds.), Periglacial Geomorphology. John Wiley and Sons, London.

Cardinali, M., Reichenbach, P., Guzzetti, F., Ardizzone, F., Antonini, G., Galli, M., Cacciano, M., Castellani, M., Salvati, P., 2002. A geomorphological approach to the estimation of landslide hazards and risks in Umbria, Central Italy. Natural Hazards and Earth System Sciences 2, 57-72.

Carmean, W.H., 1972. Site index curves for upland oaks in the Central States. Forest Science 18, 102-120.

Carrara, A., Guzzetti, F., Cardinali, M., Reichenbach, P., 1999. Use of GIS Technology in the prediction and monitoring of landslide hazard. Natural Hazards 20, 117-135.

Cook, E.R., Kairiukstis, L.A., 1990. Methods of Dendrochronology Applications in the Environmental Sciences. Kluwer, London.

Desloges, J.R., Ryder, J.M., 1990. Neoglacial history of the Coast Mountains near Bella Coola, British Columbia. Canadian Journal of Earth Sciences 27, 281-290.

Douglass, A.E., 1929. The secret of the Soutwest soved by talkative tree rings. The National Geographic Magazine 56, 736-770.

Fantucci, R., Sorriso-Valvo, M., 1999. Dendrogeomorphological analysis of a slope near Lago, Calabria (Italy). Geomorphology 30, 165-174.
Giardino, J.R., Shroder, J.F., Lawson, M.P., 1984. Tree-ring analysis of movement of a rock glacier complex on Mount Mestas, Colorado, USA. Arctic and Alpine Research 16, 299-309.

Goudie, A., 2006. Global warming and fluvial geomorphology. Geomorphology 79, 384-394.

Haeberli, W., Rickenmann, D., Zimmermann, M., Rösli, U., 1990. Investigation of 1987 debris flows in the Swiss Alps: general concept and geophysical soundings. IAHS Publication 194, 303-310.

Hebertson, E.G., Jenkins, M.J., 2003. Historic climate factors associated with major avalanche years on the Wasatch Plateau, Utah. Cold Regions Science and Technology 37, 315-332.

Labhart, T.P., 2004. Geologie der Schweiz, 6th edn. Ott Verlag, Thun.

Lenhart, D.J., 1972. An alternative procedure for improving height-age data from stem analysis. Forest Science 18, 332

May, C.L., Gresswell, R.E., 2004. Spatial and temporal patterns of debris-flow deposition in the Oregon Coast Range, USA. Geomorphology 57, 135-149.

McCarthy, D.P., Luckmann, B.H., 1993. Estimating ecesis for tree-ring dating of moraines: a comparative study from the Canadian Cordillera. Arctic, Antarctic, and Alpine Research 25, 63-68.

McCarthy, D.P., Luckmann, B.H., Kelly, P.E., 1991. Sampling height-age error correction for spruce seedlings in glacial forefields, Canadian Cordillera. Arctic and Alpine Research 23, 451-455.

Pasuto, A., Soldati, M., 2004. An integrated approach for hazard assessment and mitigation of debris flows in the Italian Dolomites. Geomorphology 61, 59-70.

Perret, S., Stoffel, M., Kienholz, H., 2006. Spatial and temporal rockfall activity in a forest stand in the Swiss Prealps - a dendrogeomorphological case study. Geomorphology 74, 219-231.

Pfister, C., 1999. Wetternachhersage. 500 Jahre Klimavariationen und Naturkatastrophen 1496-1995. Paul Haupt, Bern.

Pierson, T.C., 2007. Dating young geomorphic surfaces using age of colonizing Douglas fir in southwestern Washington and northwestern Orgegon, USA. Earth Surface Processes and Landforms ESPL 32, 811-831.

Rayback, S.A., 1998. A dendrogeomorphological analysis of snow avalanches in the Colorado Front Range, USA. Physical Geography 19, 502-515.

Rickenmann, D., Zimmermann, M., 1993. The 1987 debris flows in Switzerland: documentation and analysis. Geomorphology 8, 175-189.

Rinntech, 2006. LINTAB - Precision ring by ring. http://www.rinntech.com/ Products/LINTAG.htm.

Schindler, C., Cuenod, Y., Eisenlohr, T., Joris, C.L., 1993. Die Ereignisse vom 18. April und 9. Mai 1991 bei Randa (VS) - ein atypischer Bergsturz in Raten. Eclogae Geologicae Helveticae 86, 643-665.

Schweingruber, F.H., 1996. Tree Rings and Environment. Dendroecology. Paul Haupt, Bern.

Schweingruber, F.H., 2001. Holzanatomie. Paul Haupt, Bern.

Schweingruber, F.H., Eckstein, D., Serre-Bachet, F., Bräker, O.U., 1990. Identification, presentation and interpretation of event years and pointer years in dendrochronology. Dendrochronologia 8, 9-39.

Seiler, J., Zimmermann, M., 1999. Wildbachgefährdung durch den Grosse Grabe. Gutachten zur Gefahrenkarte. Geoplan, Steg.

Shroder, J.F., 1980. Dendrogeomorphology; review and new dating techniques of tree-ring dating. Progress in Physical Geography 4, 161-188.

Sigafoos, R.S., Hendricks, E.L., 1969. The time interval between stabilization of alpine glacial deposits and establishment of tree seedlings. US Geological Survey Professional Paper 650-B, B89-B93.

Stefanini, M.C., 2004. Spatio-temporal analysis of a complex landslide in the Northern Apennines (Italy) by means of dendrochronology. Geomorphology 63, 191-202.

Stefanini, M.C., Ribolini, A., 2003. Dendrogeomorphological investigations of debris-flow occurence in the Maritime Alps (northwestern Italy). In: Rickenmann, D., Chen, C.L. (Eds.), Debris-flow Hazard Mitigation: Mechanisms, Prediction, and Assessment. Millpress, Rotterdam, pp. 231-242.

Stoffel, M., Beniston, M., 2006. On the incidence of debris flows from the early Little Ice Age to a future greenhouse climate: a case study from the Swiss Alps. Geophysical Research Letters 33, L16404.

Stoffel, M., Schneuwly, D., Bollschweiler, M., Lièvre, I., Delaloye, R., Myint, M., Monbaron, M., 2005a. Analyzing rockfall activity (1600-2002) in a protection forest - a case study using dendrogeomorphology. Geomorphology 68, 224-241. 
Stoffel, M., Lièvre, I., Conus, D., Grichting, M., Raetzo, H., Gärtner, H., Monbaron, M., 2005b. 400 years of debris flow activity and triggering weather conditions: Ritigraben, Valais, Switzerland. Arctic, Antarctic, and Alpine Research 37, 387-395.

Stoffel, M., Lièvre, I., Monbaron, M., Perret, S., 2005c. Seasonal timing of rockfall activity on a forested slope at Täschgufer (Swiss Alps) - a dendrochronological approach. Zeitschrift für Geomorphologie 49, 89-106.

Stoffel, M., Wehrli, A., Kühne, R., Dorren, L.K.A., Perret, S., Kienholz, H., 2006. Assessing the protective effect of mountain forests against rockfall using a 3D simulation model. Forest Ecology and Management 225, 113-122.

Strunk, H., 1997. Dating of geomorphological processes using dendrogeomorphological methods. Catena 31, 137-151.
Vaganov, E.A., Hughes, M.K., Shashkin, A.V., 2006. Growth Dynamics of Conifer Tree Rings. Springer, Berlin.

Wilkerson, F.D., Schmid, G.L., 2003. Debris flows in Glacier National Park, Montana: geomorphology and hazards. Geomorphology 55, 317-328.

Winter, L.E., Brubaker, L.B., Franklin, J.F., Miller, E.A., DeWitt, D.Q., 2002. Initiation of an old-growth Douglas fir stand in the Pacific Northwest: a reconstruction from tree-ring records. Canadian Journal of Forest Research 32, 1039-1056

Zimmermann, M., Mani, P., Romang, H., 1997. Magnitude-frequency aspects of alpine debris flows]. Eclogae Geologicae Helveticae 90, 415-420. 